\title{
Winter rye as a bioenergy feedstock: impact of crop maturity on composition, biological solubilization and potential revenue
}

\author{
Xiongjun Shao ${ }^{1,2}$, Kay DiMarco ${ }^{3}$, Tom L Richard ${ }^{3}$ and Lee R Lynd ${ }^{1,2,4^{*}}$
}

\begin{abstract}
Background: Winter annual crops such as winter rye (Secale cereale L) can produce biomass feedstock on seasonally fallow land that continues to provide high-value food and feed from summer annuals such as corn and soybeans. As energy double crops, winter grasses are likely to be harvested while still immature and thus structurally different from the fully senesced plant material typically used for biofuels. This study investigates the dynamic trends in biomass yield, composition, and biological solubilization over the course of a spring harvest season.

Results: The water soluble fraction decreased with increasing maturity while total carbohydrate content stayed roughly constant at about $65 \%$. The protein mass fraction decreased with increasing maturity, but was counterbalanced by increasing harvest yield resulting in similar total protein across harvest dates. Winter rye was ground and autoclaved then fermented at $15 \mathrm{~g} / \mathrm{L}$ total solids by either (1) Clostridium thermocellum or (2) simultaneous saccharification and cofermentation (SSCF) using commercial cellulases (CTec2 and HTec2) and a xylose-fermenting Saccharomyces cerevisiae strain. Solubilization of total carbohydrate dropped significantly as winter rye matured for both $\mathrm{C}$. thermocellum (from approximately $80 \%$ to approximately 50\%) and SSCF (from approximately $60 \%$ to approximately $30 \%$ ). C. thermocellum achieved total solubilization 33\% higher than that of SSCF for the earliest harvest date and 50\% higher for the latest harvest date. Potential revenue from protein and bioethanol was stable over a range of different harvest dates, with most of the revenue due to ethanol. In a crop rotation with soybean, recovery of the soluble protein from winter rye could increase per hectare protein production by 20 to $35 \%$.

Conclusions: Double-cropping winter rye can produce significant biomass for biofuel production and feed protein as coproduct without competing with the main summer crop. During a 24-day harvest window, the total carbohydrate content remained relatively constant while the early-harvest yielded much higher carbohydrate solubilization for both C. thermocellum fermentation and SSCF. C. thermocellum fermentation achieved higher carbohydrate solubilization than SSCF across all growth stages tested. Although winter rye's yield, composition, and biological reactivity change rapidly in the spring, it offers a substantial and stable income across the harvest season and thus flexibility for the farmer.
\end{abstract}

Keywords: Winter rye, Secale cereale L, Unpretreated, Lignocellulosic biomass, Growth stage, Boot stage, Harvest maturity, Biological solubilization, Carbohydrate solubilization, Protein recovery, Consolidated bioprocessing, SSCF, Clostridium thermocellum

\footnotetext{
* Correspondence: Lee.R.Lynd@Dartmouth.edu

${ }^{1}$ Thayer School of Engineering at the Dartmouth College, 14 Engineering

Drive, Hanover, NH 03755, USA

${ }^{2}$ DOE BioEnergy Science Center, Oak Ridge National Laboratory, Oak Ridge,

TN 37831, USA

Full list of author information is available at the end of the article
}

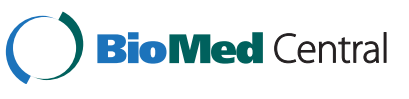

(c) 2015 Shao et al.; licensee BioMed Central. This is an Open Access article distributed under the terms of the Creative Commons Attribution License (http://creativecommons.org/licenses/by/4.0), which permits unrestricted use, distribution, and reproduction in any medium, provided the original work is properly credited. The Creative Commons Public Domain Dedication waiver (http://creativecommons.org/publicdomain/zero/1.0/) applies to the data made available in this article, unless otherwise stated. 


\section{Background}

Lignocellulosic biomass is of interest for sustainable production of fuels and chemicals [1]. Winter cover crops could be good feedstocks because their production uses readily available farm equipment and techniques, there is little or no competition with food crops [2], they can positively impact soil and water quality [3-5], and these winter crops offer important feed protein coproduct opportunities [5]. In much of the United States corn belt cover crops are commonly established in September or October and harvested or plowed under in late April or early May, so they do not interfere with summer annuals like corn or soybeans. This 'off-season' production offers potential synergies rather than competition with food crops and is thus an attractive way to integrate bioenergy crops with traditional agricultural systems. Because these are annual crops, they have a lower initial investment than perennial bioenergy crops and may be more attractive to farmers concerned about long-term biomass markets during the early stages of biofuel industrial development. Spring-harvested winter crops will contain significant protein nitrogen and other plant and animal nutrients. Recovery of such nutrients for animal feed is a potential added source of revenue and may offer life cycle benefits compared to alternative modes of feed production.

Among the variety of legume and non-legume plants commonly used as winter crops, winter rye (Secale cereale $L$ ) shows the highest yield potential in the temperate corn belt including Pennsylvania [6]. Winter rye is an annual grain crop that has been traditionally grown as animal feed as well as for flour and beverages, and is today primarily grown as a cover crop for soil and water conservation. Growing winter rye as a second crop on land also used to grow corn and soy could produce 150 million dry tons per year in the USA [2], which has a liquid fuel potential comparable to that of the current US ethanol industry. In many temperate agricultural regions, winter rye and other winter grains would be harvested before reaching full maturity. These immature grasses are structurally different than the fully senesced plant material typically used for biochemical conversion to biofuel and have long been known to be much more digestible than mature grasses by both livestock farmers and ruminant nutritionists [7]. Among many considerations, evaluating winter rye as a biofuel feedstock thus requires an understanding of the impact of plant maturity on biochemical processes. Sun and Chen [8] measured the sugar yield of winter rye straw after various sulfuric acid pretreatment severities followed by enzymatic hydrolysis with cellulases. A maximum of $197.1 \mathrm{mg}$ of total reducing sugars per gram of dry matter was reported. They found the major compositional components to be glucan (33.12\%), acid insoluble lignin
(19.80\%), xylan (10.46\%), Ash (6.15\%), and arabinan (2.47\%). However, senesced winter rye straw remaining after grain harvest is more mature than winter rye grown as a lignocellulosic double crop and harvested before or at flowering.

Although there are several growth stage scales that describe the maturity of cereal grasses, they have similar physiological descriptions and terms. Starting with 'germination', there are then several stages of 'seedling growth' followed by 'tillering', which is the addition of leaves to the main shoot; 'stem elongation'; 'booting', where the seed head is detectable inside of the stem; 'heading', which is when the seed head becomes visible, also called 'inflorescence emergence'; 'flowering', also called 'anthesis'; and lastly, 'grain development', an example of which is 'soft dough' and death or dormancy. In the Northeast, winter rye grown as a cover or second crop will rarely make it to flowering by early May when farmers are eager to plant their summer crops. The compositional difference between young and mature plants is likely to be a factor when estimating fuel yield and costs. As the growing season progresses, yield is increased but the feedstock's amenability to biochemical conversion processes may be decreased. Decades of research into the use of cereal grasses for animal forage have clearly shown a decrease in digestibility as plants mature [7].

Several prior studies have investigated the changes in winter rye composition as a function of maturity. Kantar et al. [9] sampled weekly from tillering to dough development and characterized each stage in terms of crude protein $(\mathrm{CP})$, neutral detergent fiber (NDF), and in vitro true digestibility (IVTD). In biomass energy terms, NDF can be described an undifferentiated combination of cellulose, hemicellulose, and lignin while IVTD is a measure of digestibility in a buffer/rumen fluid mixture. Fisher and Fowler [10] started sampling at late boot stage in 10-day intervals till maturity and analyzed for $\mathrm{CP}$, digestible organic matter (DOM), NDF, and acid detergent fiber (ADF). The hemicellulose can be estimated as the difference between NDF and ADF, but lignin was not measured so percent cellulose cannot be deduced. Helsel and Thomas [11] include lignin but analyzed the later growth stages of heading, milk, and soft doughgrowth stages. All of the studies discussed above showed decreased digestibility with plant maturity and several point to boot stage as a physiological indicator of the optimal time to harvest for high digestibility balanced with a decent yield for ruminant feed applications. Harvest stage trials on rye and other small grains used as whole crops for forage show that the tradeoff for boot stage harvesting is a $30 \%$ to $60 \%$ reduction in yield compared to soft dough stage [12]. Harvesting a winter grain energy double-crop at the soft dough state could be an 
option in the southern regions of the corn belt, but the greater yield may still have a tradeoff with digestibility in the context of an industrial biorefinery.

Various process configurations have been proposed for biological processing of lignocellulosic biomass to produce fuels and chemicals, including separate hydrolysis and fermentation (SHF), simultaneous saccharification and fermentation (SSF), simultaneous saccharification and cofermentation (SSCF), and consolidated bioprocessing (CBP) [13]. Fungal cellulase hydrolysis combined with yeast fermentation is a prominent model system for SHF, SSF, and SSCF. Clostridium thermocellum fermentation, potentially in co-culture with a companion 5carbon sugar utilization strain, is a prominent model system for CBP. Commercial deployment of C. thermocellum or other thermophiles offers a great potential for cost reduction by eliminating costly cellulase addition while consolidating capital equipment. Additional improvements on yield and titer are necessary for commercial application, although genetic tools have already been successfully applied to increase ethanol yield of $C$. thermocellum and T. saccharolyticum fermentations [14,15].

In the lignocellulosic biofuel field, the focus of most studies has been woody feedstocks or senescent grass harvested at the end of the season. For such feedstocks, hydrolysis yields using industry standard fungal cellulases are generally low (e.g., $\leq 20 \%$ ) so some form of pretreatment is thought to be required in order to achieve the high hydrolysis yields necessary for commercial viability. After an intensive (and expensive) pretreatment process, lignocellulose conversion via enzymatic hydrolysis using fungal cellulases typically achieves about $70 \%$ to $90 \%$ cellulose hydrolysis yields with on the order of 5 days required for hydrolysis and fermentation [16,17]. Grass forage, by contrast, is usually harvested or grazed while immature at intervals of a few weeks. When fed to livestock, the grass enters the ruminant stomach without any pretreatment other than mastication, and cellulose solubilization of $60 \%$ to $80 \%$ is typically achieved in the rumen in about $24 \mathrm{~h}$ [18]. We hypothesize that the enzymes and microorganisms used in SSCF and CBP can mimic the rumen microbial ecosystem and digest a high percentage of the carbohydrates found in immature plants without conventional pretreatment.

This study was undertaken with the objectives of advancing the understanding of dynamic trends over the spring harvest season with respect to plant maturity and biomass characteristics, the impact of these trends on biological conversion and potential products and revenue, and comparing the relative effectiveness of fungal cellulase and $C$. thermocellum fermentation at mediating solubilization. In order to be relevant to double cropping with corn and soybeans in the Northeastern United States, our study starts with younger growth stages than much of the previous work and includes measurements for lignin since it has been demined to be highly negatively correlated with digestibility $[7,19]$.

\section{Results and discussion \\ Crop maturity and yield}

Winter rye samples were collected at four different times during the spring of 2012, starting with April 16 and ending on May 10 which is the recommended planting date for corn in Pennsylvania. On April 16, the nonfertilized plots displayed a mix of stem elongation and booting but the fertilized plots consisted of plants in the stages of late booting and inflorescence (seed head emergence). On May 4, approximately $30 \%$ of plants in the fertilized plots had started to flower and continued to flower until the last harvest date of May 10, by which time the majority of the non-fertilized plants were beginning to flower. Nitrogen deficiency is known to delay the reproductive phonological development of plants [20,21]. The observed differences in plant maturation rates between fertilizer treatments indicate a nitrogen deficiency in the soil that likely impacted the protein content reported.

For the paired fertilizer treatments, plants without nitrogen fertilizer were less mature during the early harvests (Table 1) and consistently had lower biomass yield $(P$ value $=0.002)$ than those fertilized with $60 \mathrm{~kg}$ per hectare N. Biomass yield increased until around the third harvesting date (May 4, 2012) when the seed heads emerged, and then plateaued without much change for the fourth harvesting date which occurred at the time of flowering.

\section{Feedstock characterization}

Samples from each winter rye sampling event (Table 1) were analyzed with respect to water solubility and composition, with the results shown in Table 2. Detailed composition of the water soluble and insoluble fractions is provided in supplemental Additional file 1: Tables S1 and S2. The water soluble fraction decreased as the winter rye matured, dropping from over 30\% to around 15\% in 25 days. Soluble carbohydrate content decreased with the soluble fraction but insoluble carbohydrates increased as a fraction of overall mass, making the total carbohydrate content relatively stable at around $65 \%$ for all harvesting dates. Acetyl groups as a fraction of dry weight were about constant. Total protein as a fraction of total mass and water soluble protein as a fraction of total protein both decreased for later harvesting dates, and the lignin fraction of total mass increased as the plants matured (Table 2).

\section{Carbohydrate conversion by $C$. thermocellum compared to} SSCF

Solubilization of winter rye was investigated at a low (approximately $10 \mathrm{~g} / \mathrm{L}$ ) carbohydrate loading rate (roughly 
Table 1 Production data for winter rye samples

\begin{tabular}{lcllc}
\hline Harvesting date & Fertilization $(\mathbf{k g ~ N} / \mathbf{h a})$ & Sample ID designation & Maturity & Biomass yield (tons/ha) \\
\hline April 16, 2012 & 0 & April 16-0 N & Stem elongation, booting & $3.92 \pm 0.29$ \\
April 16, 2012 & 60 & April 16-60 N & Late booting, start of heading & $6.28 \pm 0.68$ \\
April 27, 2012 & 0 (wilted on field) & April 27-0 N-wilted & Late booting, start of heading & $5.41 \pm 0.60$ \\
April 27, 2012 & 0 & April 27-0 N & Late booting, start of heading & $5.41 \pm 0.60$ \\
April 27, 2012 & 60 & April 27-60 N & Heading & $6.84 \pm 0.87$ \\
May 4, 2012 & 0 & May 4-0 N & Heading & $5.63 \pm 0.46$ \\
May 4, 2012 & 60 & May 4-60 N & Heading and start of Flowering & $8.46 \pm 0.99$ \\
May 10, 2012 & 0 & May 10-0 N & Flowering & $5.89 \pm 1.52$ \\
May 10, 2012 & 60 & May 10-60 N & Flowering & $8.50 \pm 0.58$ \\
\hline
\end{tabular}

$15 \mathrm{~g} / \mathrm{L}$ total substrate) using two conversion systems: (1) fermentation by $C$. thermocellum and (2) simultaneous saccharification and cofermentation using commercial cellulase preparations ( $\mathrm{CTec} 2$ and $\mathrm{HTec} 2$ ) and a xylosefermenting strain of Saccharomyces cerevisiae. A comparison of total carbohydrate solubilization between SSCF and C. thermocellum fermentation is shown in Figure 1 (raw data in Additional file 1: Table S3). Contributions from the water soluble and insoluble fractions are also shown for each conversion system. The water soluble fraction was assumed to be solubilized $100 \%$. The overall carbohydrate solubilization in the water insoluble fraction is shown in Additional file 1: Figure S1, and solubilization of individual carbohydrate components glucan, xylan, and arabinan can be found in Additional file 1: Figures S2, S3, and S4. Between the April 16 harvest date and the May 10 harvest date, the total carbohydrate solubilization dropped from $82 \%$ to around $50 \%$ for C. thermocellum fermentation while it dropped from about $60 \%$ to $30 \%$ for SSCF. When accounting for water insoluble fraction of biomass only, solubilization ranged from $72 \%$ to $42 \%$ over the sampling period for C. thermocellum and from $38 \%$ to $12 \%$ for SSCF (Additional file 1: Figure S1). C. thermocellum achieved much higher overall total carbohydrate solubilization (approximately $20 \%$ of the original carbohydrate present, corresponding to 30 to $50 \%$ greater solubilization) compared to SSCF, primarily because conversion of insoluble carbohydrate was approximately twice as high for C. thermocellum as compared to SSCF throughout the sampling period. Carbohydrate solubilization was slightly higher for the samples without nitrogen fertilization compared to the $60 \mathrm{~kg} \mathrm{~N} / \mathrm{ha}$ fertilizer rate, likely because of the more advanced maturity of the fertilized plants. However, statistical analysis turned out that there were only nitrogen fertilization effects on the samples of April 16 and April 27 for C. thermocellum, and there were no nitrogen fertilization effects on all sample for SSCF.

Carbohydrate solubilization was observed to decrease as winter rye matured. As shown in Figure 2A, carbohydrate solubilization was negatively correlated with increasing lignin content, but was positively correlated with the percent of protein that is soluble (Figure $2 \mathrm{~B}$ ). The recalcitrance of cellulosic biomass to biological attack is a complex and not fully understood phenomenon, with contributing factors including inaccessibility to enzymes

Table 2 Composition of winter rye samples on a dry matter (DM) basis

\begin{tabular}{|c|c|c|c|c|c|c|c|c|c|c|c|c|c|}
\hline \multirow[t]{2}{*}{ Sample ID } & \multirow{2}{*}{$\begin{array}{l}\text { Soluble } \\
\text { fraction } \\
\text { of DM }\end{array}$} & \multirow[t]{2}{*}{ Carbohydrate } & \multicolumn{2}{|c|}{ Carbohydrate } & \multirow[t]{2}{*}{ Acetyl } & \multirow[t]{2}{*}{ Protein } & \multicolumn{2}{|l|}{ Protein } & \multirow[t]{2}{*}{ Lignin } & \multirow[t]{2}{*}{ Ash } & \multirow[t]{2}{*}{ Total } & \multicolumn{2}{|l|}{ Unknown } \\
\hline & & & Insoluble & Soluble & & & Insoluble & Soluble & & & & Insoluble & Soluble \\
\hline April 16-0 N & $36.4 \%$ & $64.8 \%$ & $41.4 \%$ & $23.4 \%$ & $2.2 \%$ & $8.7 \%$ & $1.2 \%$ & $7.5 \%$ & $9.6 \%$ & $0.5 \%$ & $85.8 \%$ & $8.6 \%$ & $5.6 \%$ \\
\hline April $16-60 \mathrm{~N}$ & $32.8 \%$ & $63.6 \%$ & $44.1 \%$ & $19.6 \%$ & $2.4 \%$ & $8.8 \%$ & $1.3 \%$ & $7.5 \%$ & $10.2 \%$ & $0.5 \%$ & $85.6 \%$ & $8.7 \%$ & $5.7 \%$ \\
\hline $\begin{array}{l}\text { April 27-0 N- } \\
\text { wilted }\end{array}$ & $30.0 \%$ & $65.5 \%$ & $44.0 \%$ & $21.4 \%$ & $2.4 \%$ & $6.5 \%$ & $1.3 \%$ & $5.2 \%$ & $12.0 \%$ & $0.8 \%$ & $87.2 \%$ & $9.4 \%$ & $3.4 \%$ \\
\hline April 27-0 N & $28.6 \%$ & $67.0 \%$ & $47.4 \%$ & $19.6 \%$ & $2.6 \%$ & $6.6 \%$ & $1.7 \%$ & $4.8 \%$ & $12.3 \%$ & $0.6 \%$ & $89.0 \%$ & $6.8 \%$ & $4.2 \%$ \\
\hline April 27-60 N & $27.9 \%$ & $64.7 \%$ & $47.0 \%$ & $17.7 \%$ & $2.6 \%$ & $6.9 \%$ & $2.0 \%$ & $4.9 \%$ & $12.2 \%$ & $0.6 \%$ & $86.9 \%$ & $7.8 \%$ & $5.3 \%$ \\
\hline May 4-0 N & $19.3 \%$ & $64.8 \%$ & $53.6 \%$ & $11.2 \%$ & $3.0 \%$ & $6.0 \%$ & $1.8 \%$ & $4.2 \%$ & $14.3 \%$ & $0.6 \%$ & $88.7 \%$ & $7.5 \%$ & $3.9 \%$ \\
\hline May 4-60 N & $20.6 \%$ & $64.4 \%$ & $52.2 \%$ & $12.2 \%$ & $2.7 \%$ & $6.5 \%$ & $2.3 \%$ & $4.2 \%$ & $14.2 \%$ & $0.6 \%$ & $88.4 \%$ & $7.3 \%$ & $4.3 \%$ \\
\hline May $10-0 \mathrm{~N}$ & $15.2 \%$ & $65.4 \%$ & $56.3 \%$ & $9.1 \%$ & $3.0 \%$ & $4.6 \%$ & $1.9 \%$ & $2.6 \%$ & $15.6 \%$ & $0.7 \%$ & $89.2 \%$ & $7.4 \%$ & $3.4 \%$ \\
\hline May $10-60 \mathrm{~N}$ & $16.5 \%$ & $65.3 \%$ & $55.0 \%$ & $10.3 \%$ & $2.8 \%$ & $5.3 \%$ & $2.6 \%$ & $2.7 \%$ & $16.0 \%$ & $0.6 \%$ & $90.1 \%$ & $6.5 \%$ & $3.4 \%$ \\
\hline
\end{tabular}

Note: the values in 'Total' are the sum of the italic values. 


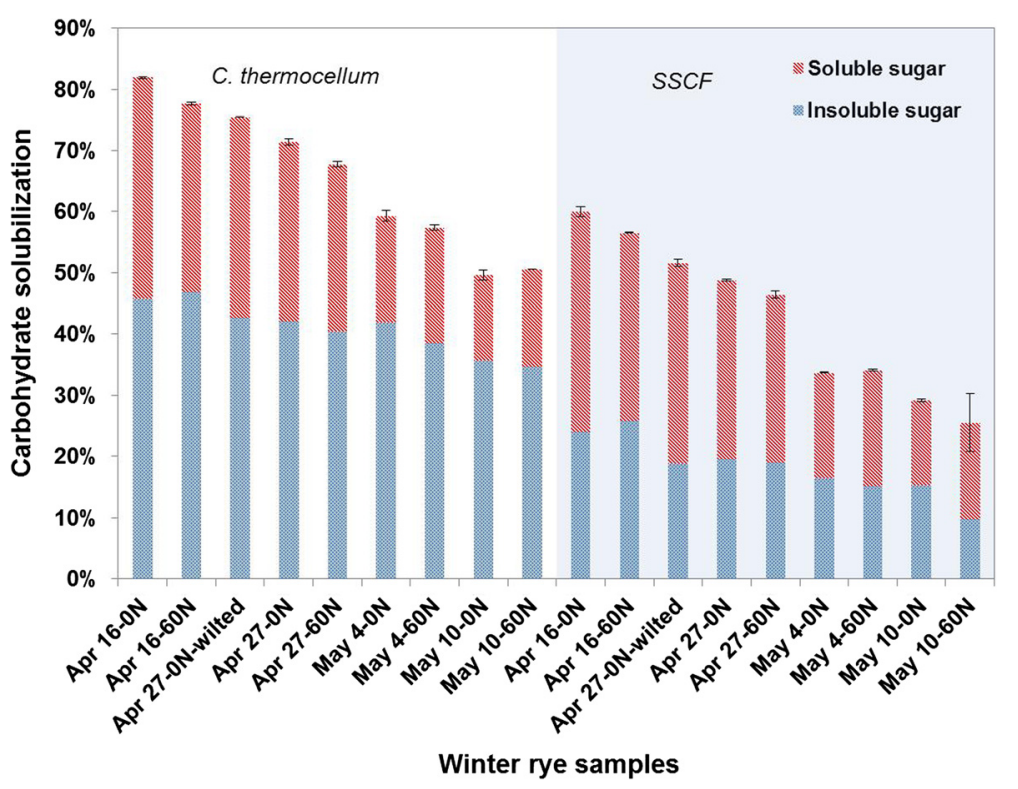

Figure 1 Total carbohydrate solubilization by C. thermocellum fermentation and SSCF for various winter rye samples (error bars are from duplicate fermentations).

and microbes, chemical linkages between carbohydrate and non-carbohydrate components, and unproductive binding of enzymes to lignin [22-24]. The greater effectiveness of $C$. thermocellum compared to SSCF using fungal cellulases is notable, not easily explained, and an interesting topic for future research. This difference is particularly puzzling since the cellulosome, thought to be primarily responsible for solubilization by $C$. thermocellum $[25,26]$, has a molecular weight over an order of magnitude larger than the largest enzyme produced by fungal cellulases and thus might be expected to be less effective at accessing glycosidic bonds.

\section{Potential products and revenue}

As shown in Figure 3A, total carbohydrate harvested increases for later harvest dates while solubilized carbohydrate is quite flat. Gross protein is relatively flat while soluble protein has a decreasing trend as winter rye matures (Figure 3B). For either carbohydrate or protein, adding nitrogen fertilization significantly increased the system output (up to about 50\% increase).

We calculate potential revenue for winter rye as a bioenergy feedstock by assuming that the solubilized carbohydrate will be converted into ethanol and sold at a price of $\$ 0.66 / \mathrm{L}$ and that the soluble protein can be recovered for feed protein and sold for $\$ 900 / \mathrm{t}$. This revenue can be expressed in terms of unit land area or unit biomass weight as shown in Figure 4, and in either case ethanol represents most of the revenue. On a per-hectare basis (of particular relevance to a farmer with a fixed land area), the potential revenue is relatively constant through most of the sampling period but falls off at the last harvest date (Figure 4A). Thus, farmers might have flexibility to choose harvesting dates for winter rye within a several week window depending on the weather and timing for planting the summer crop. As with summer annual crops, adding nitrogen fertilizer to poor soil significantly increases potential revenue by an amount that will often more than cover the cost of fertilization. Decreasing protein content and decreasing digestibility are reflected in potential revenue per ton dry feedstock decreasing as winter rye matures (Figure 4B). This implies that the price for winter rye per unit weight will likely drop as it mature, even as more biomass is produced.

Increasing costs of protein feeds for livestock is a concern for USDA [27]. Protein from winter rye as a winter crop can potentially add significantly to US feed production. With typical values of $44.5 \mathrm{bu} / \mathrm{acre}, 60 \mathrm{lb} / \mathrm{bu}$, and $40 \%$ protein content for soybean, the protein output is 1.2 ton/ha. Based on the soluble protein values in Figure 3B, a winter rye second crop would increase protein output per unit land by 0.25 to 0.4 ton/ha or about $20 \%$ to $35 \%$. However, the feed value of recovered winter rye protein for dairy, cattle, swine, and poultry also needs to be evaluated. Although it has been demonstrated that differences in cultivars are far less significant than differences in maturity, there is likely some yield gain to be made from a study across cultivars that includes data from a range of growth stages, as varieties traditionally used for soft dough stage harvest may not be those best suited for early harvest [12]. 

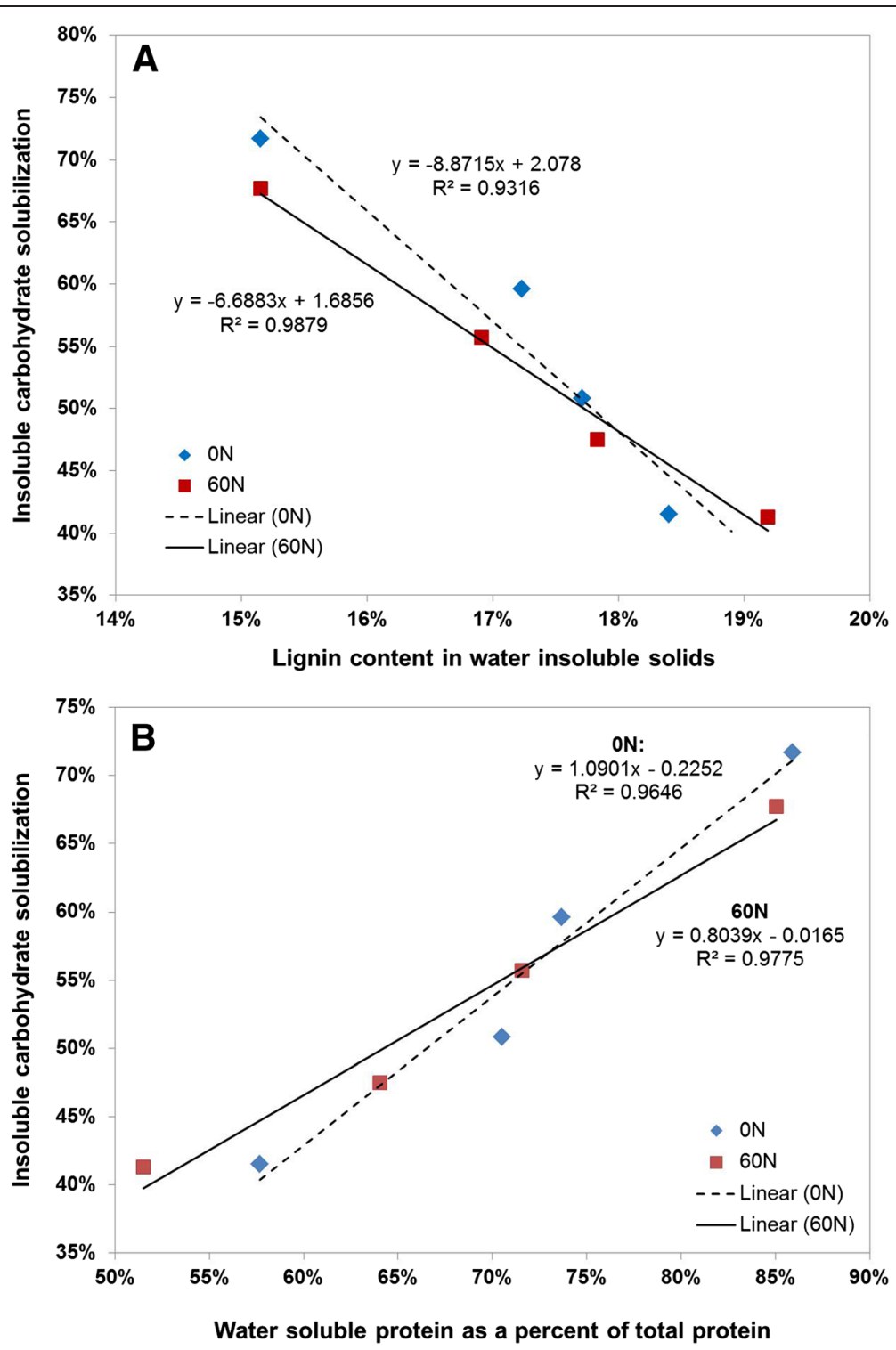

Figure 2 Insoluble carbohydrate solubilization by C. thermocellum as a function of (A) lignin content of water insoluble solids and (B) water soluble protein as a percent of total protein.

\section{Conclusions}

As a winter crop, winter rye can provide significant lignocellulosic feedstock for biofuel production per unit land area before planting main summer crop. Winter rye changes composition and biological reactivity rapidly in the spring. Immature winter rye is more amenable for $C$. thermocellum fermentation than SSCF (approximately $20 \%$ difference). Planting winter rye as winter crop can add significantly to farmer's income. If pricing was based on quality, as it is for forage, potential revenue would be quite stable for different harvest dates, which offers flexible timing for harvesting. Biofuel production using winter rye as feedstock could provide significant feed protein as coproduct.

\section{Methods}

\section{Winter rye planting and harvesting}

The cultivar Aroostook rye was planted at a density of 150 lbs/acre on 19 September 2011 in Rock Springs, PA on a Hagerstown silty clay loam soil. For the samples with fertilization (ammonium sulfate, 21-0-0), $60 \mathrm{~kg} \mathrm{ni-}$ trogen per hectare $(\mathrm{kg} / \mathrm{ha})$ were hand applied in the fall at planting. Three field replicates of one half square meters each were hand harvested leaving two inches stubble. Yields were estimated on a dry weight basis after drying in a $105^{\circ} \mathrm{C}$ oven until the mass was constant $(24$ to $28 \mathrm{~h}$ ). The plant material was air dried indoors on racks until the moisture level stabilized (3 or 4 days), with the exception of one large non-fertilized plot that 

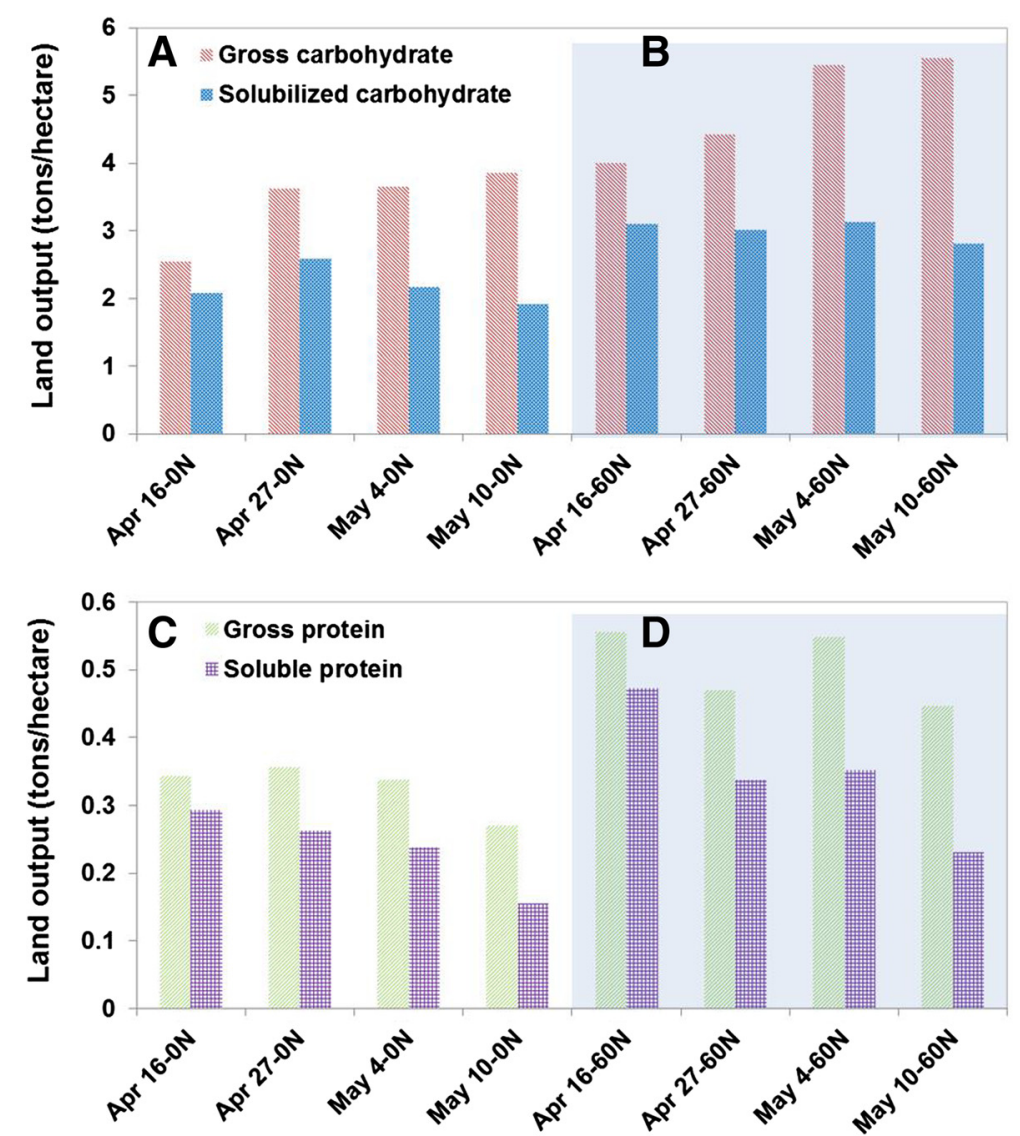

Figure 3 Unit land output for gross carbohydrate, solubilized carbohydrate, gross protein, and soluble protein as a function of harvest time (A and C: no added nitrogen, B and D: $60 \mathrm{~kg} / \mathrm{ha}$ nitrogen).

was harvested mechanically on April 27, wilted in the field for a 24-h period, then air dried indoors without racks but with periodic turning. A description of the biomass samples characterized and then fermented is provided in Table 1. Samples were taken on each harvesting date from both 0 and $60 \mathrm{~kg} / \mathrm{ha}$ fertilization plots. Samples used in this study were milled to pass through a $0.5 \mathrm{~mm}$ screen using the RETSCH ultra-centrifugal mill ZM 200.

\section{Strains, enzymes, and culturing media}

A xylose utilizing S. cerevisiae strain (Mascoma Corporation, Lebanon, NH, USA) prepared in YPD media (Sigma Y1375, St. Louis, MO, USA) was used for SSCF inoculation. The KN medium, developed by Kadam and Newman [28] and consisting of $0.3 \%(v / v)$ corn steep liquor supplemented by $5 \mathrm{mM} \mathrm{MgSO}_{4}$, was used in all SSCF experiments. Cellic CTec2 and HTec2 were kindly provided by Novozymes (Franklinton, NC, USA). C. thermocellum DSM 1313 was from DSMZ (Braunschweig, Germany). Chemically-defined media for thermophilic clostridia (MTC), with components in solutions A (carbohydrate), B (citrate and bicarbonate buffer), C (nitrogen source), D (minerals and reducing agent), E (vitamins), and F (supplemental MOPS buffer), was prepared according to Shao et al. [29] with the exception that solution A contained winter rye sample as substrate. All chemicals were reagent grade and were obtained from Sigma (St. Louis, MO, USA), unless indicated otherwise.

\section{SSCF}

A $0.75 \mathrm{~g}$ winter rye sample was added into $125-\mathrm{ml}$ serum bottles and supplemented with $41 \mathrm{ml}$ DI water and $0.2 \mathrm{~g} \mathrm{CaCO}_{3}$. The bottles were crimp-sealed, purged with $\mathrm{N}_{2}$, and sterilized by autoclaving at $121^{\circ} \mathrm{C}$ for $35 \mathrm{~min}$. After cooling, a $5 \mathrm{ml}$ filter-sterilized solution consisting of $0.15 \mathrm{ml}$ corn-steep liquor, $0.03 \mathrm{~g} \mathrm{MgSO} 4$, and $4.85 \mathrm{ml} \mathrm{DI}$ water was added by syringe. The bottles were then injected with $2 \mathrm{ml}$ filter-sterilized enzyme solution consisting $0.0425 \mathrm{ml}$ cellulase complex Cellic CTec2 (10 mg protein/g total solids), $0.0209 \mathrm{ml}$ endoxylanase Cellic HTec2 (5 mg protein/g total solids), and $1.936 \mathrm{ml}$ DI water. Finally, $2 \mathrm{ml}$ yeast inocula prepared in YPD media at $35^{\circ} \mathrm{C}$ was injected. The bottles were placed in a shaking incubator (New Brunswick Scientific, Innova 4080, Enfield, CT, USA) with temperature 

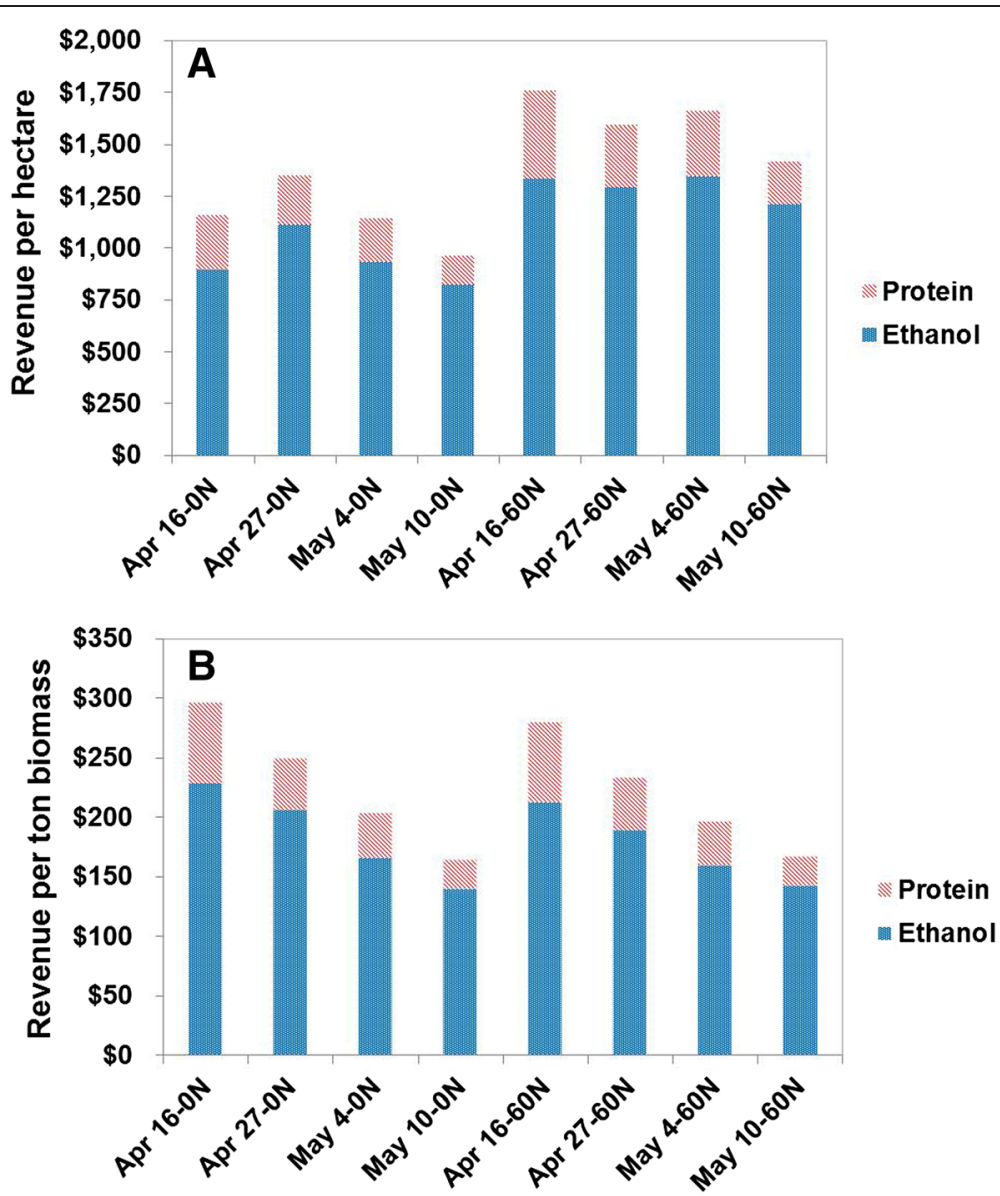

Figure 4 Revenue potential on the basis of unit land area (A) or unit biomass output (B) as a function of harvest time (assumed ethanol price: $\$ 0.66 / \mathrm{L}$, protein price: $\$ 900 / \mathrm{t})$.

controlled at $35^{\circ} \mathrm{C}$ and rotation speed set at $200 \mathrm{rpm}$. After incubating for $120 \mathrm{~h}$, the content of an entire bottle was collected and centrifuged. The supernatant was discarded after sampling for HPLC measurement. The pellets were resuspended to $50 \mathrm{~mL}$ with DI water and centrifuged again. The resulting pellets were analyzed for residual glucan, xylan, and arabinan to calculate carbohydrate solubilization.

\section{C. thermocellum fermentation}

Winter rye was ground so that the particles could pass through a $0.5 \mathrm{~mm}$ screen. A sample of $0.75 \mathrm{~g}$ was added into $125-\mathrm{ml}$ serum bottles and supplemented with $35 \mathrm{ml}$ DI water. The bottles were crimp-sealed, purged with $\mathrm{N}_{2}$, and sterilized by autoclaving at $121^{\circ} \mathrm{C}$ for $35 \mathrm{~min}$. After that, $2 \mathrm{ml} \mathrm{B}, 1 \mathrm{ml} \mathrm{C,} 1 \mathrm{ml} \mathrm{D}, 1 \mathrm{ml} \mathrm{E}$, and $5 \mathrm{ml} \mathrm{F}$ stock solutions were added by syringe. The bottles were then injected with $5 \mathrm{ml}$ inocula from an exponential phase culture grown on $5 \mathrm{~g} / \mathrm{L}$ Avicel PH 105. The bottles were placed in a shaking incubator (New Brunswick Scientific, Innova 4080, Enfield, CT, USA) with temperature controlled at $55^{\circ} \mathrm{C}$ and rotation speed set at $200 \mathrm{rpm}$.
Sample collection and processing were the same as described for SSCF.

\section{Analytical methods}

Water soluble fraction of winter rye samples was determined by measuring weight loss after incubating $15 \mathrm{~g} / \mathrm{L}$ sample at $55^{\circ} \mathrm{C}$ in a shaking incubator for $1 \mathrm{~h}$ followed by washing the remaining solids three times with the same amount of water. The carbohydrate content in the water insoluble fraction of winter rye samples and residual pellets collected and freeze-dried after SSCF and C. thermocellum fermentation were determined by quantitative saccharification [30], with biomass quantities scaled-down to one third. For carbohydrate content in the water soluble fraction of winter rye samples, dilute acid hydrolysis was performed by adding $0.125 \mathrm{ml} 72 \%$ (wt) $\mathrm{H}_{2} \mathrm{SO}_{4}$ to $28.725 \mathrm{ml}$ supernatant and autoclaving at $121^{\circ} \mathrm{C}$ for $1 \mathrm{~h}$. Product concentrations were obtained using a Waters HPLC system (\#2695, Milford, MA, USA) with an Aminex HPX-87H column (Bio-rad, Hercules, CA) operated at $60^{\circ} \mathrm{C}$ and an RI detector. A mobile phase of $5 \mathrm{mM} \mathrm{H}_{2} \mathrm{SO}_{4}$ was used at a flow rate of $0.6 \mathrm{~mL} / \mathrm{min}$. 
Carbohydrate solubilization was calculated as a percentage of originally-present glucan, xylan, or arabinan solubilized, based on analysis of residual solids. Protein content in the winter rye samples was calculated using a factor of 6.25 from nitrogen content determined by combustion approach on a Shimadzu TOC/TON analyzer (TOC- $\mathrm{V}_{\mathrm{CPH}}$ and TNM-1).

\section{Additional file}

Additional file 1: Supplemental material. Table S1. Composition of water soluble fraction of winter rye samples. Table S2. Composition of water insoluble fraction of winter rye samples. Figure S1. Overall carbohydrate solubilization of the water insoluble fraction. Figure S2. Glucan solubilization of the water insoluble fraction. Figure S3. Xylan solubilization of the water insoluble fraction. Figure S4. Arabinan solubilization of the water insoluble fraction. Table 1. Production data for winter rye samples.

\section{Abbreviations}

ADF: acid detergent fiber; CBP: consolidated bioprocessing; CP: crude protein; DOM: digestible organic matter; IVTD: in vitro true digestibility; NDF: neutral detergent fiber; SHP: separate hydrolysis and fermentation; SSCF: simultaneous saccharification and co-fermentation; SSF: simultaneous saccharification and fermentation.

\section{Competing interests}

Lee R. Lynd is a shareholder in Enchi Corporation, which has commercial interests involving cellulosic biofuels.

\section{Authors' contributions}

XS performed C. thermocellum fermentation and SSCF and some feedstock characterization. KD performed biomass harvesting, drying, and some feedstock characterization. All authors (XS, KD, TR, and LL) participated in designing the study, have revised the paper critically for intellectual content, and have read and approved the final manuscript.

\section{Acknowledgements}

XS and LL were supported by the BioEnergy Science Center (BESC), a U.S. Department of Energy (DOE) Research Center supported by the Office of Biological and Environmental Research in the DOE Office of Science, Oak Ridge National Laboratory, and Mascoma Corporation. Oak Ridge National Laboratory is managed by University of Tennessee UT-Battelle LLC for the Department of Energy under Contract No. DE-AC05-000R22725. KD and TR were supported by the Agriculture and Food Research Initiative Competitive Grant No. 2012-68005-19703 from the USDA National Institute of Food and Agriculture. We thank Bill Curran, Ph.D. and the Department of Crop and Soil Sciences at the Pennsylvania State University for providing the plant material used in this study.

\section{Author details}

${ }^{1}$ Thayer School of Engineering at the Dartmouth College, 14 Engineering Drive, Hanover, NH 03755, USA. ${ }^{2}$ DOE BioEnergy Science Center, Oak Ridge National Laboratory, Oak Ridge, TN 37831, USA. ${ }^{3}$ Penn State University, 225 Agricultural Engineering Building, University Park, PA 16802, USA. ${ }^{4}$ Enchi Corporation, Lebanon, NH 03766, USA.

Received: 11 November 2014 Accepted: 12 February 2015 Published online: 27 February 2015

\section{References}

1. Lynd L, Laser M, Bransby D, Dale B, Davison B, Hamilton R. How biotech can transform biofuels. Nat Biotechnol. 2008;26:169-72.

2. Feyereisen GW, Camargo GGT, Baxter RE, Baker JM, Richard TL. Cellulosic biofuel potential of a winter rye double crop across the U.S. corn - soybean belt. Agron J. 2013;105:631-42.
3. Strock JS, Porter PM, Russelle MP. Cover cropping to reduce nitrate loss through subsurface drainage in the northern U.S. corn belt. J Environ Qual. 2004;33:1010-6.

4. Lu YC, Watkins KB, Teasdale JR, Abdul-Baki AA. Cover crops in sustainable food production. Food Rev Int. 2000;16:121-57.

5. Heggenstaller AH, Anex RP, Liebman M, Sundberg DN, Gibson LR. Productivity and nutrient dynamics in bioenergy double-cropping systems. Agron J. 2008;100:1740-8.

6. Duiker SW, Curran W. Cover Crops. In Editor Amanda K, editor. The Agornomy Guide. The Pennsylvania State University; 2014. pp. 123-31.

7. van Soest PJ. The Nutritional Ecology of the Ruminant. 2nd ed. Ithaca, NY: Cornell University Press; 1994

8. Sun Y, Cheng J. Dilute acid pretreatment of rye straw and bermudagrass for ethanol production. Bioresour Technol. 2005;96:1599-606.

9. Kantar M, Sheaffer C, Porter P, Krueger E, Ochsner TE. Growth stage influences forage yield and quality of winter rye. Forage Grazinglands. 2011;9(1).

10. Fisher $\amalg$, Fowler DB. Predicted forage value of whole plant cereals. Can J Plant Sci. 1975:55:975-86.

11. Helsel ZR, Thomas JW. Small grains for forage. J Dairy Sci. 1987;70:2330-8.

12. Collar C, Fulton A, Campbell M. Maturity at harvest effects on yield and quality of winter cereals for silage. In 23rd California Alfalfa Symposium; Visalie, CA. 1993; 174-184.

13. Lynd LR, Wyman CE, Gerngross TU. Biocommodity engineering. Biotechnol Prog. 1999;15:777-93.

14. Shaw AJ, Podkaminer KK, Desai SG, Bardsley JS, Rogers SR, Thorne PG, et al Metabolic engineering of a thermophilic bacterium to produce ethanol at high yield. PNAS. 2008;105:13769-74.

15. Tripathi SA, Olson DG, Argyros DA, Miller BB, Barrett TF, Murphy DM, et al. Development of pyrF-based genetic system for targeted gene deletion in Clostridium thermocellum and creation of a pta mutant. Appl Environ Microbiol. 2010. doi:10.1128/AEM. 01484-10.

16. Humbird D, Davis R, Tao L, Kinchin C, Hsu D, Aden A, et al. Process design and economics for biochemical conversion of lignocellulosic biomass to ethanol. Golden, CO, USA. NREL/TP-5100-47764; 2011.

17. Tao L, Aden A, Elander RT, Pallapolu VR, Lee YY, Garlock RJ, et al. Process and technoeconomic analysis of leading pretreatment technologies for lignocellulosic ethanol production using switchgrass. Bioresour Technol. 2011;102:11105-14.

18. Moran J. Tropical dairy farming: Feeding management for small holder dairy farmers in the humid tropics. Collingwood VIC 3066, Australia: Landlinks Press; 2005.

19. Cherney JH, Marten GC. Small grain crop forage potential: I. Biological and chemical determinants of quality, and yield. Crop Sci. 1982;22:227-31.

20. McCullough DE, Girardin P, Mihajlovic M, Aguilera A, Tollenaar M. Influence of $\mathrm{N}$ supply on development and dry matter accumulation of an old and a new maize hybrid. Can J Plant Sci. 1994;74:471-7.

21. Uhart SA, Andrade FH. Nitrogen deficiency in maize: I. effects on crop growth, development, dry matter partitioning, and kernel set. Crop Sci. 1995;35:1376-83.

22. Himmel ME, Ding SY, Johnson DK, Adney WS, Nimlos MR, Brady JW, et al. Biomass recalcitrance: engineering plants and enzymes for biofuels production. Science. 2007;315:804-7.

23. Beckham GT, Matthews JF, Peters B, Bomble YJ, Himmel ME, Crowley MF. Molecular-level origins of biomass recalcitrance: decrystallization free energies for four common cellulose polymorphs. J Phys Chem B. 2011;115:4118-27.

24. Sathitsuksanoh N, Xu B, Zhao B, Zhang YHP. Overcoming biomass recalcitrance by combining genetically modified switchgrass and cellulose solvent-based lignocellulose pretreatment. PLoS One. 2013;8:e73523.

25. Bayer EA, Belaich JP, Shoham Y, Lamed R. The cellulosomes: multienzyme machines for degradation of plant cell wall polysaccharides. Annu Rev Microbiol. 2004;58:521-54.

26. Fontes CM, Gilbert HJ. Cellulosomes: highly efficient nanomachines designed to deconstruct plant cell wall complex carbohydrates. Annu Rev Biochem. 2010;79:655-81.

27. Trostle R, Marti D, Rosen S, Westcott P. Why have food commodity prices risen again? Washington, DC, USA. USDA Outlook No. (WRS-1103); 2011.

28. Kadam KL, Newman MM. Development of a low-cost fermentation medium for ethanol production from biomass. Appl Microbiol Biotechnol. 1997;47:625-9. 
29. Shao X, Jin M, Guseva A, Liu C, Balan V, Hogsett D, et al. Conversion for Avicel and AFEX pretreated corn stover by Clostridium thermocellum and simultaneous saccharification and fermentation: Insights into microbial conversion of pretreated cellulosic biomass. Bioresour Technol. 2011;102:8040-5.

30. Ruiz R, Ehrman T. LAP procedure \#2 - Determination of carbohydrates in biomass by high performance liquid chromatography. Golden, CO, USA: National Renewable Energy Laboratory; 1996.

Submit your next manuscript to BioMed Central and take full advantage of:

- Convenient online submission

- Thorough peer review

- No space constraints or color figure charges

- Immediate publication on acceptance

- Inclusion in PubMed, CAS, Scopus and Google Scholar

- Research which is freely available for redistribution 